\title{
The productivity of spring rapeseed hybrids depending on different levels of mineral nutrition and humic fertilizer
}

\author{
Ekaterina Lupova ${ }^{1, *}$, Dmitry Vinogradov ${ }^{1}$, Olga Zaharova ${ }^{1}$, and Dmitry Kucher $^{2}$ \\ ${ }^{1}$ Department of Agronomy and Agrotechnologies, Ryazan State Agrotechnological University Named after P.A. Kostychev, Ryazan, \\ 390044, Russia \\ ${ }^{2}$ Agrarian and Technological Institute, People's Friendship University of Russia (RUDN), Moscow, 117198, Russia
}

\begin{abstract}
Rapeseed has a multifunctional agricultural and environmental value. According to statistics, the growth of acreage occupied by rapeseed in the Russian Federation for 10 years reached $126.8 \%$ or 872.9 thousand ha. The article provides an assessment of spring rapeseed production for oilseeds in the Clearfield system at different levels of mineral nutrition in combination with Ecorost bio-fertilizer in conditions of the Non-Chernozem Zone of Russia. The studies were carried out in 2018-2019 at an experimental agrotechnological station of Ryazan State Agrotechnological University Named after P.A. Kostychev (FSBEI HE RSATU) on gray forest soils. High efficiency of the Clearfield production system has been established. The introduction of $\mathrm{N}_{180} \mathrm{P}_{120} \mathrm{~K}_{60}$ complex for pre-sowing cultivation contributed to the formation of maximum indicators of the rapeseed yield formula and size. The highest yields were shown by Ecorost variants: Kultus $\mathrm{KL} \mathrm{N}{ }_{180} \mathrm{P}_{120} \mathrm{~K}_{60}(27.8 \mathrm{dt} / \mathrm{ha})$, Cultus $\mathrm{KL} \mathrm{N} \mathrm{N}_{180}(27.3 \mathrm{dt} / \mathrm{ha})$, Cebra KL $\mathrm{N}_{180} \mathrm{P}_{120} \mathrm{~K}_{60}, \mathrm{~N}_{180}$ (24.4 dt/ha), Cyclus KL $\mathrm{N}_{180}, \mathrm{~N}_{90} \mathrm{P}_{60} \mathrm{~K}_{60}(26.6 \mathrm{dt} / \mathrm{ha})$. The maximum profitability of rapeseed oilseeds production was obtained on $\mathrm{N}_{180}$ variant Kultus KL (133.5\%).
\end{abstract}

\section{Introduction}

In 2018 and 2019 the yield of oilseeds in Russia amounted to 19.6 million tons. Sunflower remains the main oilseed crop, giving 12.7 million tons (65\% of the total). In recent years, soy and rapeseed production has been growing rapidly [1].

The sown area of winter and spring rapeseed in farms of all categories in the Russian Federation in 2019 amounted to $1,561.3$ thousand ha. In general, analysts have noted an increase in the area occupied by these crops by $126.8 \%$ or 872.9 thousand ha for 10 years. Among the regions, the Altai Territory is the leader in terms of expanding the area under rapeseed (in 2019 the share in the total area was $11.8 \%$ ), Krasnoyarsk Territory $(9.3 \%)$ and Omsk region $(8.4 \%)$. In 2019 the sown area of rapeseed also included Kemerovo region, Tula region, Ryazan region and Lipetsk region [2].

Spring rapeseed is a crop that has changed dramatically in recent decades as a result of human activities. It is expressed both in appearance and in chemical composition [3]. Spring rapeseed is a crop that has several advantages relative to other crops. This is ensured, first of all, by early maturity, resistance to cold, high reproduction rate, significant productivity potential, and diverse use $[4,5]$.

The use of rapeseed is not limited to nutritional purposes. It has become a source of raw materials for biofuels. It is actively used for technical purposes, as well as to replenish the feed base in animal husbandry and poultry farming. Rapeseed is able to provide animals with green food for a long time [6, 7]. Possible environmental impacts and rising fossil fuel prices explain the popularity of plant-based biofuels.

Rapeseed byproducts (oilcake and meal) with a high content of oil and protein, and optimal balance in amino acid composition are used as high-energy and protein components of diets for farm animals and poultry [8]. The introduction of oilseed meal in the feed composition increases the efficiency of fattening of young cattle at the final stage [9].

Rapeseed has a multifunctional agricultural and environmental value. Being a green manure crop, it provides soil with organic matter with the optimal ratio of carbon and nitrogen, increases its fertility and has a bio herbicidal and bio fungicidal effect [10]. The indicated property of rapeseed can otherwise be noted only in a small group of crops $[11,12]$.

A special role in the biologization of agriculture is given to the production of spring rapeseed seeds for technical purposes. Over the last quarter of century, there has been a fourfold increase in the sown area of oilseeds in the Russian Federation and a fivefold increase in the sown area of rapeseed.

Break-even production of oilseed rapeseed can start at a yield of at least $10 \mathrm{dt} / \mathrm{ha}$. However, soil and climatic conditions do not always allow the varietal potential to

* Corresponding author: katya.lilu@mail.ru 
be realized. Note that Ryazan region is very suitable for growing spring rapeseed [13].

Note that rapeseed varieties and hybrids cultivated using Clearfield technology are an innovative solution in obtaining a high-quality crop yield. Clearfield technology is the combined action of Nopasaran herbicide and special hybrids that are resistant to this herbicide. Yield potential and stability, and resistance to pathogens are the most important selection goals along with the quality of oil and meal, the absence of erucic acid and the low glucosinolates content or two-zero (00) quality [14]. High efficiency in spring rapeseed is also expressed regardless of weather conditions, largely due to the active work of two active substances, which determines the novelty and relevance of research.

\section{Problem statement}

Plant protection from diseases and pests has become an important aspect of rapeseed cultivation technology. There are numerous growth regulators, bio fertilizers, fungicides, herbicides and insecticides at the market to protect rape, thanks to which it is possible to control the most important diseases, weeds and pests.

The purpose of the research is to evaluate the production of spring rapeseed for oilseeds in the Clearfield system at different levels of mineral nutrition in combination with Ecorost bio fertilizer in conditions of the Non-Chernozem Zone of Russia.

Thus, oilseeds are still income-generating crops for agricultural producers abroad and in the Russian Federation, but it is necessary to create a domestic raw material base for the stable production of vegetable oils. Despite advantages of new varieties and hybrids of spring rape, their biology and cultivation technology in the Non-Chernozem Zone of Russia are still insufficiently studied and require detailed research, which determines the direction of our research.

\section{Materials and methods}

The experiment is a three-factor one. Crop productivity was studied at different levels of mineral nutrition (factor A): $\mathrm{N}_{180} \mathrm{P}_{120} \mathrm{~K}_{60}, \mathrm{~N}_{90} \mathrm{P}_{60} \mathrm{~K}_{60}, \mathrm{~N}_{180}, \mathrm{~N}_{90}$. Dose $\mathrm{N}_{180} \mathrm{P}_{120} \mathrm{~K}_{60}$ was obtained when calculating the norms of fertilizer application, taking into account the adjustment, and calculating the balance of nutrients on gray forest soils in the conditions of the experimental agricultural station of FSBEI HE RSATU. When developing the fertilizer system, the correct ratio between individual types and forms of mineral fertilizers was established and optimal doses, terms and methods of fertilizing under spring rapeseed were calculated. The main part of mineral fertilizers was applied for autumn plowing and the rest of fertilizers were used in spring before sowing.

The objects of research in the experiment of 2018-2019 were hybrids of foreign breeding Cultus KL, Curry KL, Cyclus KL and Cebra KL, being hybrids of the first generation F1 (factor B). Rapeseed was cultivated using Clearfield technology. The sowing date was the first decade of May. The seeding rate of spring rapeseed was 1.25 million germinating seeds/ha. The total area of the plot was $200 \mathrm{~m}^{2}$ and the record plot was $160 \mathrm{~m}^{2}$. The replication was four-fold. The studies were based on generally accepted methods [15].

Let us present a brief description of the studied spring rapeseed hybrids.

Cultus $K L$ has its applicant party stated as Nord Deutsche Pflanzenzucht Hans-Georg Lembke KG, Germany. It is registered with the State Register of Selection Achievements with the admission region of West Siberia. It is characterized as early spring, mediumtall, with a short beak and peduncle. The maximum yield was obtained in 2014 (21.3 dt/ha). The declared growing season is 96 days, with an oil content of 46-47\%. It was included in the register of the Russian Federation in 2016.

It is characterized as a hybrid with high oil content and low content of glucosinolates. Its resistance to stress factors is successful.

Curry $K L$ was originated by Nord Deutsche Pflanzenzucht Hans-Georg Lembke KG, Germany. It was introduced as a Type-00 hybrid. In the State Register it is for the East Siberian Region (11). The leaf is green, with a strong development of lobes and medium serration of edges. It has medium flowering. The vegetation period is 104 days and the weight of 1,000 seeds is $4-4.1 \mathrm{~g}$. It is characterized by oil content of 42.0-45.1\%. The highest yield was obtained in Krasnoyarsk Territory (41.3 dt/ha) in 2016. It was included in the register of the Russian Federation in 2017.

It is characterized as a hybrid of a new generation. It is characterized by a dense and powerful pod. It is declared as a plastic hybrid that does not require special types of soil. It belongs to the mid-season group.

Cyclus $K L$ has its originator stated as Nord Deutsche Pflanzenzucht Hans-Georg Lembke KG, Germany. It was introduced as a Type-00 hybrid. It is registered with the State Register for the West Siberian region (10) and the East Siberian region (11). It was included in the register of the Russian Federation in 2018.

The degree of development of lobes of the leaf and the dentation are weak. It has average flowering time. The peduncle is long. The maximum yield was obtained in Altai Territory (43.9 dt/ha). The growing season is about 100 days. According to variety testing in Krasnoyarsk Territory and the Republic of Khakassia, it ripened 3-6 days faster than standard variety Nadezhny 92.

The mass of 1,000 seeds is about $3.8 \mathrm{~g}$. The height of the plant is average. The plant is resistant to lodging. It has average score of the ability to shed (3.9). Seed fat content is at $46.7 \%$ of standard.

Cebra $K L$ has originator of Nord Deutsche Pflanzenzucht Hans-Georg Lembke KG, Germany. It was introduced as a Type-00 hybrid. It has early-medium flowering time. The degree of development of lobes of the leaf is medium. The plant has weak dentation of the leaf. It is characterized by intensive development in the initial phases of growth. It was included in the register of the Russian Federation in 2018. 
It is included in the State Register for the Central (3), East Siberian (11) regions for the production of oilseeds. The average yield in the Central Federal District of the Russian Federation is $15.4 \mathrm{dt} / \mathrm{ha}$. The maximum yield was obtained in Kaluga region (27.9 dt/ha).

The mass of 1,000 seeds is $4.1 \mathrm{~g}$ and the height of plants is $99-106 \mathrm{~cm}$. The oil content is 44-45\%. Resistance to lodging is $4.6-4.8$ points. The plant is resistant to shedding.

Note that all the studied hybrids are included in the State register of breeding achievements, as they have been approved for use relatively recently: Kultus KL in 2016, Curry KL in 2017, Cyclus KL in 2018 and Cebra KL in 2018.

Humic preparation Ecorost (factor C) was used as a bio-fertilizer for spring rapeseed. Ecorost is a liquid humic fertilizer, a dark brown liquid with a neutral acidity of $\mathrm{pH}$ 6.5-7.5 and humic acid content of up to $70 \mathrm{~g} / \mathrm{l}$. This humic preparation is produced from lowland peat, which has a decomposition degree of more than $30 \%$ and humidity of $50-70 \%$ with the addition of prepared water. Humic preparation is made in the Russian Federation, in the city of Ryazan. Humic preparation Ecorost belongs to hazard class 4. It is a lowhazard product. Ecorost is not phytotoxic and does not cause resistance.

Ecorost was used in the form of a prepared working solution with a consumption rate of $2501 /$ ha at a dose of $400 \mathrm{ml} / \mathrm{ha}$ for rapeseed hybrids. Spring rapeseed was treated twice with a solution: in the phase of the rosette of leaves and in the phase of the initial blossom.

Agro-technical measures for the cultivation of spring rapeseed hybrids were in accordance with recommendations adopted in the Non-Chernozem Zone of Russia.

For all experiments, the forecrop was winter wheat. Then autumn plowing was carried out to a depth of 20-22 cm with the help of Peresvet plow PPO-7-35 Almaz + K-744P. In early spring harrowing with the help of BZZS-1.0 + MTZ-1221 took place. Then the land was cultivated with the help of KPS-4.2 + MTZ1221 to a depth of $12-14 \mathrm{~cm}$. Pre-sowing cultivation was to a depth of $2-3 \mathrm{~cm}$. When pre-sowing cultivation, fertilizer RUN-1H was introduced with the help of MTZ1221.2. The introduction of mineral fertilizers was carried out according to experimental schemes. Ammonium nitrate, urea and nitrophoska were used in terms of the active substance. Sowing was carried out with seeder SSNT-16 + MTZ-82.1 to a depth of 2-3 cm.

Spring rapeseed sowing was carried out with seeds that had underwent a pre-sowing treatment. All rapeseed seeds were treated with Cruiser Rape, KS (mefenoxam $32.3 \mathrm{~g} / \mathrm{l}+$ thiamethoxam $280 \mathrm{~g} / \mathrm{l}+$ fludioxonil $8 \mathrm{~g} / \mathrm{l}$ ).

After sowing, seed rolling was performed with the help of 3KKSh-6 + MTZ-1221.2. During the growing season rapeseed plants were treated with pesticides against pests, diseases and weeds. To do it and apply the solution of humic preparation Ecorost, sprayers OP3,000 Bulgar and OPSh-15-01 and Quasar-12 backpack sprayer were used, depending on the type of treatment. They tried to carry out insecticidal treatments in a tank mixture with herbicides or fungicides. Insecticides were used against major oilseed pests such as cruciferous flea, canola beetle, and cabbage moth. Fastak, KE in a dose of 0.15 1/ha and Bi-58 New, 1-1.2 1/ha were used.

Fungicide Pictor, KS, 0.5 1/ha was used during the growing season of spring rapeseed crops either when the first signs of damage to pathogens of alternariosis, sclerotiniosis, fomosis and white rot, or as a precautionary measure.

Treatment took place no later than one month before the expected harvest for rapeseed and two months for sunflower. Treatment was carried out before the flowering of crops. Harvesting was carried out at full ripeness of crops directly with a TERRION-SAMPO SR 2010 combine.

Rapeseed was harvested when at least $75 \%$ drying of pods and humidity not higher than 10-11\%, accompanied by completion of drying. The cut height of rapeseed plants was at the level of $8-10 \mathrm{~cm}$.

\section{Results and discussion}

Mineral fertilizers are a major factor in the production of spring rapeseed seeds. This is due to the high removal of mineral nutrients from the soil with the crop yield. Dose adjustment of mineral fertilizers in the study was carried out taking into account a deficiency-free balance of nutrients, which certainly leads to stabilization of soil fertility.

When calculating the norms for applying mineral fertilizers, taking into account the adjustment, the balance of nutrients was calculated at a dose of $\mathrm{N}_{180} \mathrm{P}_{120} \mathrm{~K}_{60}$. The influence of $\mathrm{N}_{90} \mathrm{P}_{60} \mathrm{~K}_{60}, \mathrm{~N}_{180}$ and $\mathrm{N}_{90}$ levels was also studied.

The use of the Clearfield system in investigations was aimed primarily at developing a number of agronomic advantages of rapeseed production, namely, at reducing the infestation of the crop, including problematic weeds of the cruciferous family (types of mustard, colza, wild radish, and drops). When using this technology, there was no deterioration in quality indicators of the obtained crop, including the presence of glucosinolates and erucic acid in seeds.

All experimental rapeseed hybrids in the first month grew slowly, forming a powerful root system. In the second half of the growing season, an intensive growth of leaf-stem mass was observed, with an average daily weight gain of $0.6-0.7 \mathrm{t} / \mathrm{ha}$.

Note that Cebra KL hybrid had an earlier flowering time with an average degree of leaf lobe development. Cebra KL and Cultus KL were characterized by more intensive development in the initial phases of growth.

The duration of phenological phases depended on how the conditions for moisture and air temperature were formed. On average, over two years, the vegetation period for all hybrids was in the range of 89-110 days. Hybrid Cultus KL on $\mathrm{N}_{90} \mathrm{P}_{60} \mathrm{~K}_{60}$ variant without Ecorost treatment ( 89 days) was noted as more fast-ripening. In 2019 , due to the hot and dry first half of the growing season, the crop did not fully use mineral fertilizers. The main part of nutrients was used in the second half, with a large amount of precipitation in July (Fig. 1). 


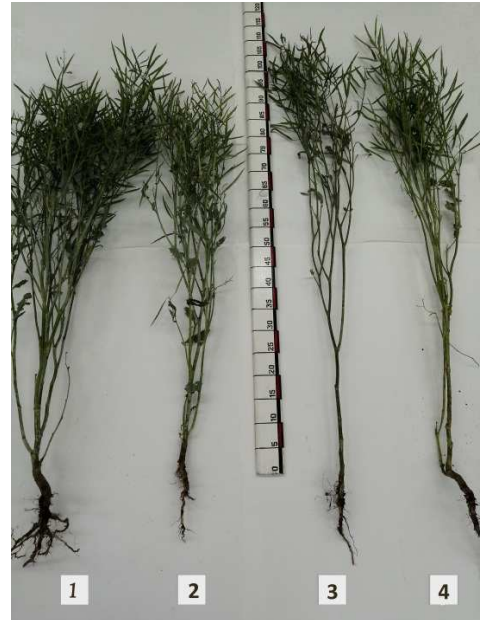

Fig. 1. Plants of spring rapeseed varieties, nutrition level $\mathrm{N}_{90} \mathrm{P}_{60} \mathrm{~K}_{60}$, without treatment with Ecorost: 1 - Cultus KL, 2 - Cebra KL, 3 - Curry KL, 4 - Cyclus KL

Note the high quality of rapeseed seed grain. All seeds were well inlaid with dressing agent Cruiser Rape, KS. On average, field germination of rapeseed was noted at the level of 93-95.5\% in 2018 and it was $87.5-90.7 \%$ in a less favorable 2019. A decrease in the germination and preservation of plants during the entire period of rapeseed development was influenced by a complex of unfavorable hydrothermal conditions and a high degree of weed contamination. The degree of damage caused by numerous pests of the crop, such as cruciferous flea, canola beetle and cabbage moth affected the development strongly. Damaged by pests, young rapeseed plants sharply reduced the growth of biomass or simply died. Weed vegetation in rapeseed agrocenosis reduced soil fertility due to the consumption of moisture reserves and nutrients, as well as oppressed crops, obscuring cultivated plants, as a result of which yield shortages and production quality decreased.

In our experiments, we ascertain the high efficiency of the Clearfield system used, where the optimization of the process of reducing weed infestation depended on just one treatment with Nopasaran herbicide. On average, after treatment with the herbicide, the total mass of weeds decreased by $76.5-89 \%$, depending on the variant.

All the studied hybrids cultivated using the Clearfield system proved themselves well in conditions of the region, where the yield varied at the level of 2.5-3.0 t/ha of oilseeds (Table 1).

The developed and deeply penetrating root system of rapeseed made it possible to withstand the stressful conditions of the growing season. All hybrids in our studies were characterized as plants with high resistance to stress factors, which could be traced to the unfavorable hot and dry period in May-June 2019.

The maximum number of pods in the yield formula was noted on variants with hybrids Cultus KL (96.0-115.6 pieces/1 plant) and Cyclus KL (90.5-109 pieces/1 plant).

All rapeseed crops were marked by uniform ripening and a compact pod. The maximum consumption of nutrients was noted at the beginning of flowering (the green pod).

Variants with rapeseed varieties Cultus KL and Cebra KL had higher efficacy of the use of humic preparation Ecorost. So, the maximum increase in oilseeds from Ecorost treatment was on variants Cultus $\mathrm{KL}, \mathrm{N}_{180}$ and Cebra KL, $\mathrm{N}_{90}$ and it amounted to $+1.5 \mathrm{dt} /$ ha. Ecorost in the studies had a growthstimulating effect and fungicidal activity, accelerated the growth and development of rapeseed plants, increased the resistance of plants to adverse conditions, helped to increase productivity and improve the quality of oilseeds. The preparation increased resistance to bacterial and fungal diseases.

The action of phosphorus-potassium fertilizers in combination with nitrogen did not have a significant increase in yield, and led to a rise in the cost of these rapeseed variants. Therefore, the most effective doses of fertilizers should be considered nitrogen ones: $\mathrm{N}_{90}$ and $\mathrm{N}_{180}$.

The highest yields were shown by Ecorost variants: Cultus KL $\mathrm{N}_{180} \mathrm{P}_{120} \mathrm{~K}_{60}$ (27.8 dt/ha), Cultus KL N 180 (27.3 dt/ha), Cebra KL N ${ }_{180} \mathrm{P}_{120} \mathrm{~K}_{60}, \mathrm{~N}_{180}(24.4 \mathrm{dt} / \mathrm{ha})$ and Cyclus KL N ${ }_{180}, \mathrm{~N}_{90} \mathrm{P}_{60} \mathrm{~K}_{60}(26.6 \mathrm{dt} / \mathrm{ha})$.

Table 1. Yield of spring rapeseed hybrids on options with the action of different levels of mineral nutrition, average for 2018-2019, $\mathrm{dt} / \mathrm{ha}$

\begin{tabular}{|c|c|c|c|c|c|c|c|c|c|c|c|c|c|}
\hline \multirow{2}{*}{$\begin{array}{c}\text { Level of } \\
\text { mineral } \\
\text { nutrition }\end{array}$} & \multirow[t]{2}{*}{ Treatment } & \multicolumn{3}{|c|}{ Cultus KL } & \multicolumn{3}{|c|}{ Cebra KL } & \multicolumn{3}{|c|}{ Curry KL } & \multicolumn{3}{|c|}{ Cyclus KL } \\
\hline & & 2018 & 2019 & average & 2018 & 2019 & average & 2018 & 2019 & average & 2018 & 2019 & average \\
\hline \multirow[t]{2}{*}{$\mathrm{N}_{90}$} & $\begin{array}{l}\text { without } \\
\text { treatment }\end{array}$ & 21.7 & 26.8 & 24.2 & 20.4 & 24.5 & 22.4 & 22.2 & 21.1 & 21.6 & 24.6 & 26.8 & 25.7 \\
\hline & Ecorost & 22.8 & 27.8 & 25.3 & 21.9 & 25.9 & 23.9 & 22.3 & 22.0 & 22.1 & 24.4 & 27.4 & 25.9 \\
\hline \multirow[t]{2}{*}{$\mathrm{N}_{180}$} & $\begin{array}{l}\text { without } \\
\text { treatment }\end{array}$ & 23.2 & 28.4 & 25.8 & 22.0 & 25.4 & 23.7 & 25.0 & 21.4 & 23.2 & 25.3 & 27.1 & 26.2 \\
\hline & Ecorost & 24.6 & 30.1 & 27.3 & 22.6 & 26.3 & 24.4 & 25.6 & 21.7 & 23.6 & 25.6 & 27.6 & 26.6 \\
\hline \multirow[t]{2}{*}{$\mathrm{N}_{90} \mathrm{P}_{60} \mathrm{~K}_{60}$} & $\begin{array}{l}\text { without } \\
\text { treatment }\end{array}$ & 20.4 & 24.6 & 22.5 & 20.4 & 24.2 & 22.3 & 21.5 & 20.9 & 21.2 & 25.6 & 27.2 & 26.4 \\
\hline & Ecorost & 22.0 & 25.2 & 23.6 & 20.7 & 24.8 & 22.7 & 21.9 & 20.8 & 21.3 & 26.5 & 26.7 & 26.6 \\
\hline \multirow[t]{2}{*}{$\mathrm{N}_{180} \mathrm{P}_{120} \mathrm{~K}_{60}$} & $\begin{array}{l}\text { without } \\
\text { treatment }\end{array}$ & 23.7 & 28.4 & 26.0 & 21.6 & 26.2 & 23.9 & 25.1 & 21.8 & 23.4 & 25.1 & 27.5 & 26.3 \\
\hline & Ecorost & 25.5 & 30.1 & 27.8 & 21.9 & 27.0 & 24.4 & 26.0 & 22.1 & 24.0 & 26.3 & 26.8 & 26.5 \\
\hline
\end{tabular}

$\mathrm{LSD}_{05} \mathrm{dt} / \mathrm{ha}$

2018 - interactions $\mathrm{ABC}-2,96$, by factors $\mathrm{AB}-2,09, \mathrm{AC}-1,48, \mathrm{BC}-1,12$

2019 - interactions $\mathrm{ABC}-3,26$, by factors $\mathrm{AB}-2,30, \mathrm{AC}-1,63, \mathrm{BC}-1,44$. 


\section{Conclusion}

The experiments revealed the high efficiency of the Clearfield production system regardless of weather and soil conditions of 2018 and 2019. The need for long-term use of the herbicidal treatment during the development of phenophase seedlings - budding, allows to vary the timing of the use of the herbicide against weeds, and apply it at the optimal time.

The introduction of $\mathrm{N}_{180} \mathrm{P}_{120} \mathrm{~K}_{60}$ complex for presowing cultivation contributed to formation of maximum indicators of the yield formula and yield of rape. Options with the introduction of only nitrogen fertilizer $\mathrm{N}_{90}$ or $\mathrm{N}_{180}$ had high yield.

Higher efficiency of humic preparation Ecorost was noted on variants with rapeseed varieties Cultus KL and Cebra KL. So, the maximum increase in oilseeds from Ecorost treatment was on variants Cultus KL, $\mathrm{N}_{180}$ and Cebra KL, $\mathrm{N}_{90}$ and amounted to $+1.5 \mathrm{dt} / \mathrm{ha}$. The use of Ecorost humic fertilizer makes it economically feasible, due to the low price of $\$ 2 / 1$ ha.

The variant with $\mathrm{N}_{180}$ for all hybrids of spring rapeseed showed high profitability of production, due to the lack of the introduction of expensive and ineffective phosphorus-potassium fertilizers. The maximum profitability of rapeseed oilseeds production was obtained on $\mathrm{N}_{180}$ variant Cultus KL (133.5 \%).

\section{References}

1. E.I. Lupova, E.A. Vysotskaya, D.V. Vinogradov, Improvement of elements of oil flax cultivation technology on gray forest soil, IOP Conf. Ser. Earth and Environmental Sci., 422, 012081 (2020)

2. D.V. Vinogradov, K.V. Naumtseva, E.I. Lupova, Use of biological fertilizers in white mustard crops in the non-Chernozem zone of Russia, IOP Conf. Ser. Earth and Environmental Sci., 341, 012204 (2019)

3. G. Robbelin, Variation in rapeseed glucosinolates and breeding for improved meal quality In: Brassica crops and wild allies: biology and breeding (Tokyo, 1980), pp. 285-299

4. R. Jonsson, B. Uppstom, Quality breeding in rapeseed. Research and results in plant breeding (Stockholm, 1986), pp. 173-184
5. G. Ciurescu, Efficiency of soybean meal replacement by rapeseed meal and/or canola seeds in commercial layer diets, Arch. Zootechn., 12, 27-33 (2009)

6. M. Rezvani, H. Kluth, M. Bulang, M. Rodehutscord, Variation in amino aciddigestibility of rapeseed meal studied in caecectomised laying hens and relationship with chemical constituents, Br. Poult. Sci., 53, 665-647 (2012)

7. M. Toghyani, A. Mohammadsalehi, A. Gheisari, S. Tabeidian, The effect of low-glucosinolate rapeseed meal in diets with multi-enzyme supplement on performance and protein digestibility in broiler chicks, J. Anim. Feed Sci., 18, 313-321 (2009)

8. D.A. Roth-Maier, M. Kirchgessner, Feeding of 00rapeseed seed to fattening chickens and laying hens, Archiv für GeHiigelkunde, 59, 241-246 (1995)

9. V. Thanaseelaan, K. Niswanathan, D. Chandrasekaran, R. Prabakaran, M. Chellapandan, Chemical composition, amino acids, minerals and antinutritional factors of rapeseed meal, J. of Vet. and Anim. Sci., 3, 101-105 (2007)

10. A.T. Farniev, I.V. Alikova, Seed productivity of spring rapeseed depending on the treatment with biological preparations, Feed product., 10, 22-25 (2009)

11. V. Vasileva, Aboveground to root biomass ratios in pea and vetch after treatment with organic fertilizer, Global J. of Environmental Sci. and Manag., 1(2), 71-74 (2015)

12. A. Ilieva, V. Vasileva, Effect of liquid organic humate fertilizer Humustim on chemical composition of spring forage pea, Banat's J. of Biotechnol., IV(7), 74-79 (2013)

13. Agroclimatic conditions of Ryazan region (Ryazan, 1989)

14. D. Shpaar et al., Rapeseed and Bird Rapeseed (Growing, Harvest, Use) (M.ID JSC "DLV Agrodelo, 2007)

15. B.A. Dospekhov, Methods of field experiment (with the basics of statistical processing of research results) (Alliance, Moscow, 1985)

\footnotetext{
* Corresponding author: katya.lilu@mail.ru
} 